\title{
EFFECT OF HYDROGEL PROVISION OF SHED AND PRP COMBINANTION ON OSTEOCLAST DECREASING IN THE ALVEOLAR BONE OF MALE WISTAR RAT (IN VIVO)
}

Rahmat Hidayat *, Muhamat Muhtar ${ }^{* *}$, Mualif Dayu Pangestu ***

${ }^{*}$ Departemen Prostodonsi Fakultas Kedokteran Gigi Universitas Islam Sultan Agung

${ }^{* *}$ Departemen Ortodonsi Fakultas Kedokteran Gigi Universitas Islam Sultan Agung

${ }^{* * *}$ Program Pendidikan Dokter Gigi Fakultas Kedokteran Gigi Universitas Islam Sultan Agung

Correspondence : $\underline{\text { drg.rahmathidayat@gmail.com }}$

\section{Keywords:}

Osteoclast, Stem Cell Human Exfoliated Decidious Teeth (SHED), Platelet Rich Plasma (PRP)

\begin{abstract}
Background: The process of orthodontic bone resorption and remodelling occur simultaneously. Areas under continuous stress experience nutritional deficiencies and hypoxia, which results in cell death and cause alveolar bone resorption. The increase in osteoclasts is associated with the inflammatory process because it is accompanied by an increase in inflammatory mediators. The combination of SHED and PRP can induce regeneration of the alveolar bone of teeth and can inhibit the bone resorption process thereby suppressing the inflammatory process.

Method: This research method was experimental post-test only control group design, with a total sample of 32 individuals treated with PRP gel, SHED gel, a combination of PRP and SHED, and povidone iodine with a duration of 14 days. Wedge application to the interdental teeth to produce the effect of orthodontic movement. Analysis of the one way ANOVA hypothesis test found that there was a significant difference in the reduction of osteoclasts in each experimental group $(P<0.05)$.

Result: It can be concluded that the mean osteoclast reduction in the PRP group was 359 \pm 107.3 , SHED 392 \pm 170.5 , the combination of PRP and SHED $480 \pm 151.3$, povidone iodine $480 \pm 151.3$.

Conclusion: There is an effect of the combination of SHED and PRP on the reduction of osteoclasts in the alveolar bone of male Wistar rat.
\end{abstract}

\section{PENDAHULUAN}

Ortodonsi yaitu proses pergerakan secara mekanik yang dapat mengembalikan gigi ke posisi periodesium. Gigi akan menggeser posisinya yang menghasilkan kenaikan osteoclast di daerah kompres dan kenaikan osteoblast di daerah tension ${ }^{1}$. Ketika osteoclast meresorpsi tulang, osteoblast akan meningkatkan osteoprotegerin untuk menghentikan kerja osteoclast sehingga resorpsi dan aposisi tulang akan terjadi bersamaan 2

Resorpsi tulang alveolar dapat disebabkan oleh pergerakan dari efek orto apabila kerja osteoclast lebih dominan dan tidak diimbangi oleh kerja dari osteoblast ${ }^{3}$. Berawal dari peradangan pada gingival dan ligamentum periodontal dalam keadaan yang lebih parah sehingga menyebabkan kerusakan tulang alveolar ${ }^{4}$. Penanganan penyakit periodontal dewasa ini lebih fokus pada menghilangkan faktor penyebab terjadinya penyakit periodontal ${ }^{5}$. Namun hal ini tidak berlaku jika penyakit periodontal sudah melibatkan kerusakan atau resorpsi tulang ${ }^{6}$. mengembalikan struktur dan fungsi dari jaringan periodontal, termasuk mengatasi terjadinya resorpsi tulang alveolar adalah Salah satu gold standart perawatan periodontal 7 .

Kombinasi SHED (Stem Cell Human Exfoliated Decidious Teeth) dan PRP ( Platetel Rich Plasma ) dapat menginduksi regenerasi tulang 
alveolar gigi dan dapat menghambat proses resorpsi tulang pada kasus periodontitis ${ }^{8}$. Kemampuan osteoinductive dan osteogenic dari SHED akan digunakan pada regenerasi tulang alveolar ${ }^{9}$. PRP merupakan plasma darah yang kaya akan platelet yang mengandung PDGF, VEGF, IGF, BMP-2 yang menstimulasi kenaikan osteoblast, penurunan osteoclast dalam pembentukan tulang, dan TGF- $\beta$ yang menstimulasi pembentukan OPG sehingga jumlah ikatan RANKL dan OPG meningkat dibandingkan dengan ikatan reseptor RANK dan RANKL sehingga terbentuklah pembentukan tulang ${ }^{10}$.

Dari uraian latar belakang, maka dapat disimpulkan bahwasanya resopsi tulang alveolar bisa disebabkan karena efek orto. dari penelitian sebelumnya kombinasi SHED dan PRP dapat memperbaiki resopsi tulang tetapi masih dalam sediaan liquid yang mana kurang maksimal apabila diaplikasikan di mukosa.

Oleh karena itu, penulis akan melakukan penelitian tentang bagaimana pengaruh sediaan kombinasi SHED dan PRP dalam bentuk hidrogel terhadap penurunan Osteoclast.

Penelitian ini diharapkan dapat memberi informasi ilmiah tentang potensi osteogenesis dari kombinasi SHED dan PRP sebagai host modulation therapy pada resorpsi tulang alveolar, sehingga layak dijadikan dasar pengembangan terapi terhadap resorpsi tulang alveolar dengan memanfaatkan potensi osteogenesis dari kombinasi SHED dan PRP yang dapat memicu terjadinya regenerasi tulang alveolar.

\section{METODE PENELITIAN}

Penelitian berikut adalah penelitian true eksperimental dengan rancangan penelitian posttest only control group design pada 32 ekor tikus jantan Wistar. Sample didapatkan dari populasi tikus jantan Wistar jantan dengan teknik pengambilan simple random sampling.

Adapun tahap peneltian mencakup Isolasi SHED, Isolasi PRP, pembuatan gel, perlakuan pada hewan coba, pengaplikasian material pada hewan coba dan pembuatan preparat Histopatologi.

\section{HASIL PENELITIAN}

Hasil penelitian pengaruh sediaan hidrogel kombinasi SHED dan PRP terhadap Penurunan osteoclast pada tulang alveolar tikus wistar jantan disajikan dalam tabel dibawah:

Tabel 1.1 Penurunan osteoclast

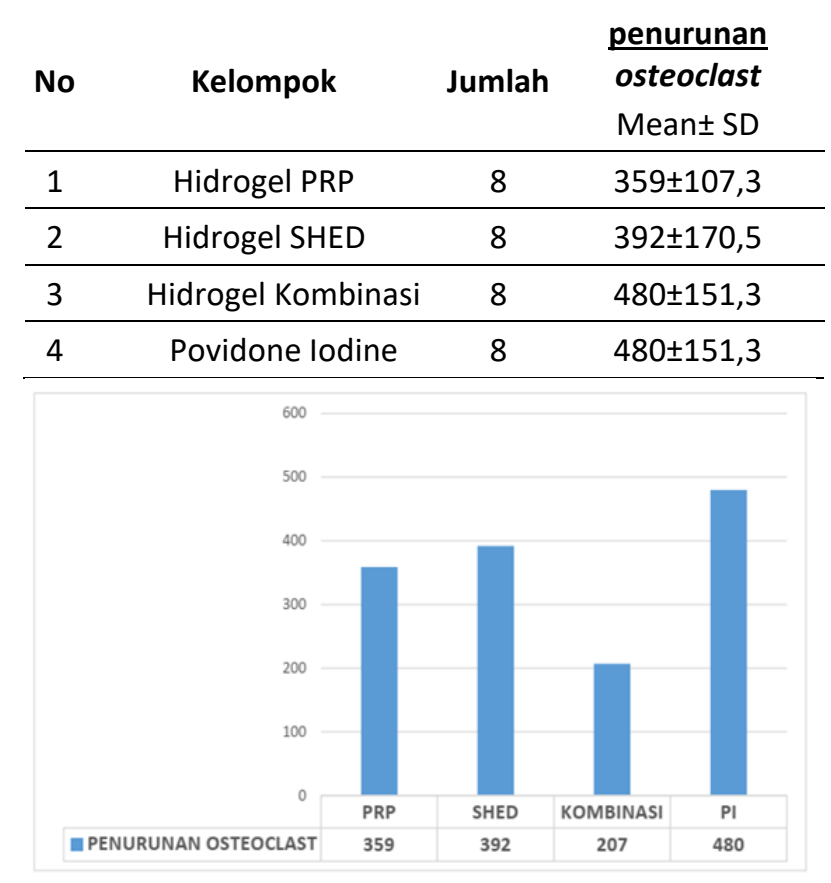

Gambar 1.1 Rata-rata penurunan osteoclast pada Kelompok Perlakuan

Tabel diatas menunjukkan jumlah rerata penurunan osteoclast pada tulang alveolar rahang hewan coba. Dari data 1.1 dapat disimpulkan bahwa rerata penurunan osteoclast terendah pada kelompok kombinasi PRP dan SHED $=207$ dan rerata penurunan osteoclast tertinggi pada kelompok povidone iodine $=480$.

Hasil gambar pengamatan penurunan osteoclast pada kelompok perlakuan didominasi 
oleh warna biru. Hal tersebut sangat kontras bila dibandingkan dengan kelompok control (povidone iodine) yang didominasi warna cokelat pada sitoplasma sel Hasil pengamatan mikroskop penurunan osteoclast pada setiap kelompok

perlakuan yang tampak pada gambar 1.2 berikut:

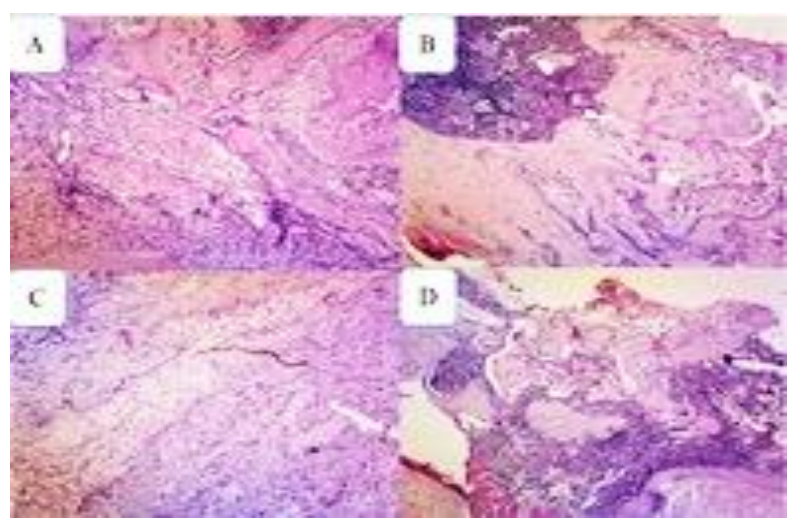

Gambar 1.2 penurunan osteoclast A) penurunan osteoclast kelompok hidrogel PRP dengan pembesaran 100X B) penurunan osteoclast kelompok hidrogel SHED dengan pembesaran 100X C) penurunan osteoclast kelompok hidrogel SHED dan PRP dengan pembesaran 100X D) penurunan osteoclast kelompok poviodon ioidone dengan pembesaran 100X.

Tabel 1.2 Hasil uji normalitas Shapiro-Wilk

\begin{tabular}{ccc}
\hline Kelompok & Sig. (P) & Keterangan \\
\hline PRP & 0,793 & $\begin{array}{c}\text { Data } \\
\text { terdistribusi } \\
\text { normal }\end{array}$ \\
\hline SHED & 0,756 & $\begin{array}{c}\text { Data } \\
\text { terdistribusi } \\
\text { normal }\end{array}$ \\
\hline $\begin{array}{c}\text { Kombinasi } \\
\text { PRP dan } \\
\text { SHED }\end{array}$ & 0,490 & $\begin{array}{c}\text { Data } \\
\text { terdistribusi } \\
\text { normal }\end{array}$ \\
\hline $\begin{array}{c}\text { Povidone } \\
\text { lodine }\end{array}$ & 0,576 & $\begin{array}{c}\text { Data } \\
\text { terdistribusi } \\
\text { normal }\end{array}$ \\
\hline
\end{tabular}

Uji normalitas yang telah dilakukan menunjukkan data masing-masing kelompok terdistribusi normal dengan nilai $P>0.05$. didapatkan nilai PRP $=0,793$, SHED $=0,756$, Kombinasi $=0,490$ dan $\mathrm{PI}=0,576$ selanjutnya dilakukan uji homogenitas dan disajikan pada tabel dibawah:
Tabel 1.3 Hasil uji homogenitas

\begin{tabular}{lll}
$\begin{array}{l}\text { Kenaikan } \\
\text { Skor }\end{array}$ & Sig. (P) Keterangan \\
\hline
\end{tabular}

Rata-Rata

0,062

Data homogen

Hasil uji homogenitas didapatkan sig. (P) 0,062 sehingga menunjukkan nilai $p>0,05$ maka sebaran semua data kelompok homogen. Berdasarkan uji normalitas dan homogenitas diatas, maka penelitian ini menggunakan uji One Way Anova dan dilanjutkan dengan uji post hoc $L S D$.

Tabel 1.4 Hasil uji One Way Anova

\begin{tabular}{cccc}
\hline Kelompok & P & Sig. $(\mathbf{p})$ & Hasil \\
\cline { 1 - 1 } & & & \\
\hline PRP & & & \\
$\begin{array}{c}\text { Kombinasi } \\
\begin{array}{c}\text { PRP dan } \\
\text { SHED }\end{array}\end{array}$ & 0,002 & P $<0,05$ & Signifikan \\
$\begin{array}{c}\text { Povidone } \\
\text { iodine }\end{array}$ & & & \\
\hline
\end{tabular}

Pada tabel 1.4 Hasil uji One Way ANOVA didapatkan nilai signifikan yaitu 0,002 menunjukkan bahwa nilai $p<0,05$ atau dapat disimpulkan bahwa terdapat perbedaan yang signifikan penurunan osteoclast masing-masing kelompok. Untuk melihat perbedaan antar kelompok maka dilanjutkan uji beda dengan Pos Hoc LSD.

Tabel 1.5 Hasil uji Post Hoc LSD

\begin{tabular}{|c|c|c|c|}
\hline $\begin{array}{c}\text { (I) } \\
\text { Perlakuan }\end{array}$ & $\begin{array}{c}\text { (J) } \\
\text { Perlakuan }\end{array}$ & $\begin{array}{c}\text { Perbedaa } \\
\text { n Rata- } \\
\text { Rata }\end{array}$ & $\mathbf{P}$ \\
\hline \multirow[t]{3}{*}{ PRP } & SHED & $-32,5$ & $\begin{array}{c}0,61 \\
6\end{array}$ \\
\hline & $\begin{array}{l}\text { Kombinasi } \\
\text { SHED dan } \\
\text { PRP }\end{array}$ & 152,6 & $\begin{array}{c}0,02 \\
4\end{array}$ \\
\hline & $\begin{array}{l}\text { Povidone } \\
\text { lodine }\end{array}$ & $-120,4$ & $\begin{array}{c}0,07 \\
1\end{array}$ \\
\hline \multirow[t]{3}{*}{ SHED } & PRP & 32,5 & $\begin{array}{c}0,61 \\
6\end{array}$ \\
\hline & $\begin{array}{l}\text { Kombinasi } \\
\text { SHED dan } \\
\text { PRP }\end{array}$ & 185,1 & $\begin{array}{c}0,00 \\
7\end{array}$ \\
\hline & Povidone & $-87,9$ & 0,18 \\
\hline
\end{tabular}




\begin{tabular}{lccc}
\hline & \multicolumn{1}{l}{ lodine } & \\
\hline Kombinasi \\
$\begin{array}{l}\text { SHED dan } \\
\text { PRP }\end{array}$ & PRP & $-152,6$ & 0,02 \\
& & & 4 \\
\cline { 2 - 4 } & SHED & $-185,1$ & 0,00 \\
& & & 7 \\
\cline { 2 - 4 } & Povidone & $-273,1$ & 0,00 \\
lodine & & 0 \\
\hline $\begin{array}{l}\text { Povidone } \\
\text { lodine }\end{array}$ & PRP & 120,4 & 0,07 \\
& & & 1 \\
\cline { 2 - 4 } & SHED & 87,9 & 0,18 \\
& & & 1 \\
\cline { 2 - 4 } & Kombinasi & 273,1 & 0,00 \\
& SHED dan & & 0 \\
& PRP & & \\
\hline
\end{tabular}

Dari tabel 1.5 dapat disimpulkan bahwa terdapat perbedaan yang bermakna antar kelompok perlakuan dengan nilai $(p<0,05)$. Berdasarkan penelitian diatas menunjukan bahwa kelompok yang paling bermakna adalah di kelompok hidrogel kombinasi SHED dan PRP untuk penurunan osteoclast pada tulang alveolar tikus Wistar jantan.

\section{DISKUSI}

Pemberian hidrogel kombinasi yang diaplikasikan selama 14 hari dapat menurunkan osteoclast pada tulang alveolar tikus wistar jantan secara bermakna, sehingga hipotesis penelitian ini diterima. Analisis data yang telah dilakukan dapat disimpulkan pada tabel 1.1 bahwa rerata penurunan osteoclast terendah pada kelompok kombinasi PRP dan SHED ${ }^{11}$. Pada penelitian ini kombinasi PRP dan SHED lebih efektif menurunkan osteoclast dibanding kelompok yang diaplikasikan PRP dan SHED tunggal. dikarenakan SHED yang dikombinasikan dengan PRP akan melepaskan growth factor dan juga berperan dalam proses regenerasi tulang ${ }^{12}$. Hidrogel gel SHED dan PRP pada penelitian ini ditambhakan pengikat karbomer $^{13}$ dikombinasikan dengan propilon glikol dan triethanolamine meningkatkan daya sebar selain itu dapat larut dalam air dan etanol yang menyebabkan viskositas pada konsentrasi kecil sehingga kerjanya lebih efektik pada $\mathrm{pH}$ yang luas sehingga dapat menjadi gelling agent yang baik ${ }^{14}$.
Kelompok control memiliki jumlah rerata tertinggi dari kelompok lain dikarenakan povidone iodine mempengaruhi regenerasi tulang melalui jalur antiinflamatory dan antimikrobial efek yang mana dapat memodulasi reaksi oksidasi yang terbentuk saat luka, kemudian menghambat kerja TNF-a dan Metaloproteinase yang berperan dalam kerusakan jaringan ${ }^{15}$.

Hasil uji hipotesis pada tabel 1.4 menunjukkan bahwa kelompok kombinasi PRP dan SHED lebih baik dibanding kelompok SHED, PRP, dan povidone iodine dalam menurunkan osteoclast. Sel osteoclast merupakan sel penghilang tulang yang melarutkan, mengikir tulang selama tahaptahap dari proses penghilang sampai pembuatan tulang dalam proses ortodonsi yaitu sel ini pembuatan lakuna atau lubang ${ }^{16}$. Osteoclast berperan penting dalam proses remodeling tulang dan modulasi. Peningkatan osteoclast tanpa di imbangi osteoblast pada tulang alveolar yang mengalami defek berkorelasi dengan terjadinya proses resorpsi tulang alveolar ${ }^{17}$. PRP merupakan produk turunan dari darah yang memiliki konsentrasi platelet yang tinggi sehingga memicu pertumbuhan osteoblast dan menstimulasi penyembuhan tulang dan jaringan lunak dan growth factor pada gel PRP dapat dipengaruhi oleh material gel yang ditambahkan material pengikat yaitu carbomen yang dapat larut dalam air, etanol sehingga viskositas tinggi dapat bekerja secara efektif menjadi gelling agent yang baik dapat Meningkatnya daya sebar gel pada karbomer biasanya juga dikombinasikan dengan propilen glikol dan triethanolamine ${ }^{18}$.

SHED dapat dimanfaatkan memicu pertumbuhan tulang dan transplantasi tulang potensi ini karena SHED memiliki potensi adipogenik, osteogenik, kondogenik, miogenik, neurogenic, dan osteoinduktif. ${ }^{19}$ SHED yang dipengaruhi oleh growth factor pada PRP. Growth 
factor atau TGF- $\beta$ berfungsi menghambat aktivitas osteoclast, mengatur aktivitas osteoblast dengan cara menstimulasi kemotaksis sehingga mengaktivasi sitokinesis antagonis inflamasi yang dapat menekan jumlah RANKL dengan meningkatkan serta menstabilkan jumlah OPG menyebabkan terbentuknya ikatan RANKL-OPG dan menghambat ikatan RANKL-RANK sehingga terjadilah regenerasi tulang ${ }^{20}$.

\section{KESIMPULAN}

Pemberian hidrogel kombinasi SHED dan PRP berpengaruh menurunkan jumlah osteoclast pada tikus Wistar jantan pada regenerasi tulang alveolar. Akan tetapi Perlu dilakukan penelitian lebih lanjut dalam pembuatan basis hidrogel dengan formulasi yang optimal uji klinik agar dapat diaplikaskan kepada manusia.

\section{UCAPAN TERIMAKASIH}

Terimakasih kepada kepada seluruh pihak Pusat Penelitian dan Pengembangan Bank Jaringan dan Sel Gedung Diagnostic Center RSUD Soetomo Surabaya, Integrated Biomedical Laboratory Universitas Islam Sultan Agung Semarang dan Laboratorium Patologi Anatomi Fakultas Kedokteran UNS Surakarta yang sudah membantu dalam kelancaran penelitian ini.

\section{DAFTAR PUSTAKA}

1. Li Y, Chan YW. ScienceDirect Orthodontic tooth movement: The biology and clinical implications. 2016;5(6):6539.https://doi.org/10.1016/j.kjms.2018.01.00 7

2. Younis, L. T. The Role of Components and Molecules of Periodontal Ligament in Orthodontic Tooth Movement. 2019;2(2), $1-12$. https://doi.org/10.5281/zenodo.3555157

3. Feller, L., Khammissa, R. A. G., Schechter, I., Thomadakis, G., Fourie, J., \& Lemmer, J. Biological Events in Periodontal Ligament and Alveolar Bone
Associated with Application of Orthodontic Forces; 2015.

4. Bartold, P. Periodontal Regeneration Fact of Fiction? Journal of the International Academy of Periodontology.2015;(3): 3749

5. Figueiredo; M. F. M. F. L. Non-Surgical Periodontal Therapy: Mechanical Debridement, Anti Microbial Agent, and other modalities. Journal of the International Academy of Periodontology. 2015;2(1):21-30

6. Lang, N. P. Non-Surgical Periodontal Therapy: Mechanical Debridement, Anti Microbial Agent, and other modalities. Bangkok: International Academy of Periodontology;2015.

7. Wang, L. H. Y. L. S. Stem cell- - based tooth and periodontal regeneration. 2018; 4(1):696-705. https://doi.org/10.1111/odi.12703

8. Lee, Y. H. H. J. C. Y. S. Y. Dental Stem Cell and Tooth Banking for Regenerative Medicine. J Exp Clin Med. 2010;1(2):111117.

9. Kaur, P. Platelet Rich Plasma: A Novel Bioengineering Concept. Trends Biomater.2011;25 (2): 86-90

10. Sobhana, K. T. G. C. R. Clinical Evaluation of Use of Platelet Rich Plasma in Bone Healing. 2015;14(1):67-80.

11. Mokhtar, M. F. A. K. T. P. K. DPSCs and SHED in Tissue Engineering and Regenerative Medicine. The Open Stem Cell Journal.2013; 4(3): 1-6.

12. Castillo, T. N.Comparison of Growth Factor and Platelet Concentration From Commercial Platelet-Rich Plasma Separation Systems. The American Journal of Sports Medicine. SAGE Publications Inc STM.2010; 39(2): 266271. doi: $10.1177 / 0363546510387517$

13. Raymond C Rowe, P. J. S. and M. E. Q. Handbook of Pharmaceutical Excipients, Revue des Nouvelles Technologies de l'Information; 2015.

14. Bigliardi, P. L. et al. Povidone iodine in wound healing: A review of current concepts and practices. International journal of surgery (London, England). England.2017;44(2):260-268. doi: 10.1016/j.ijsu.2017.06.073

15. Interactions, O. HHS Public Access. 2018; 59(2): 99-107. https://doi.org/10.1080/03008207.2017.12 90085. Osteoblast-Osteoclast

16. Ono, T.RANKL biology: bone metabolism, the immune system, and beyond'. Inflammation and Regeneration.2020; 3 (1):1-16 
17. Prahasanti, C. Combined Hydroxyapatite Scaffold and Stem Cell from Human Exfoliated Deciduous Teeth Modulating Alveolar Bone Regeneration via Regulating Receptor Activator of Nuclear Factor-Kb and Osteoprotegerin System;2019.

18. Mihaylova, Z. Platelet Derived Products and Periodontal Ligament Stem Cells. Archives of Stem Cell Research.2017; 7(2):34-45
19. Jayaraman, P.Stem cells conditioned medium: a new approach to skin wound healing management'.2019; 9(9):1-7. doi: 10.1002/cbin.10138

20. Qian, Y. Platelet-rich plasma derived growth factors contribute to stem cell differentiation in musculoskeletal regeneration', Frontiers in Chemistry.2017; 5(10): 1-8. doi: 10.3389/fchem.2017.00089. 